University of Nebraska - Lincoln

DigitalCommons@University of Nebraska - Lincoln

U.S. National Park Service Publications and

Papers

National Park Service

$2-20-2020$

\title{
Effects of culling white-tailed deer on tree regeneration and Microstegium vimineum, an invasive grass
}

John Paul Schmit

Elizabeth R. Matthews

Andrejs Brolis

Follow this and additional works at: https://digitalcommons.unl.edu/natlpark

Part of the Environmental Education Commons, Environmental Policy Commons, Environmental

Studies Commons, Fire Science and Firefighting Commons, Leisure Studies Commons, Natural Resource

Economics Commons, Natural Resources Management and Policy Commons, Nature and Society

Relations Commons, Other Environmental Sciences Commons, Physical and Environmental Geography

Commons, Public Administration Commons, and the Recreation, Parks and Tourism Administration

Commons

This Article is brought to you for free and open access by the National Park Service at DigitalCommons@University of Nebraska - Lincoln. It has been accepted for inclusion in U.S. National Park Service Publications and Papers by an authorized administrator of DigitalCommons@University of Nebraska - Lincoln. 


\title{
Effects of culling white-tailed deer on tree regeneration and Microstegium vimineum, an invasive grass
}

\author{
John Paul Schmit*, Elizabeth R. Matthews, Andrejs Brolis \\ National Park Service, NCR Office of Natural Resources and Science, 4598 MacArthur Blvd. NW, Washington, DC 20007, USA
}

\section{A R T I C L E I N F O}

\section{Keywords:}

Deer management

Forest regeneration

Invasive species

Tree seedlings

\begin{abstract}
A B S T R A C T
Reduction of forest regeneration due to overbrowsing by white-tailed deer is a growing concern for land managers. Abundant deer can impede forest regeneration through direct predation on tree seedlings. Additionally high deer density can facilitate the establishment of a dense understory of browse tolerant plant species that shades seedlings and persists even in the absence of deer. In response to these challenges, land managers have sought to reduce deer herds to restore tree regeneration, but few studies have evaluated the effectiveness of this management. Our study took place in Catoctin Mountain Park, a US National Park Service unit with a history of high deer density. The park has been heavily invaded by Microstegium vimineum, an invasive grass that can completely cover the forest floor. Using permanent plots established prior to the start of deer management, we were able to assess the joint effects of deer culling and $M$. vimineum on tree seedling density. We found that tree seedling density increased in response to deer reductions. $M$. vimineum cover initially increased, but then decreased. Seedling densities were higher in plots with more $M$. vimineum cover, indicating that it did not form a recalcitrant understory that would suppress regeneration. However, eight years after deer management began, few tree seedlings were $>30 \mathrm{~cm}$ tall, implying that it will be many years before they grow into the sapling stage. Our results indicate that deer culling can be an effective tool in restoring tree regeneration despite the presence of $M$. vimineum, but that success will require a long-term commitment.
\end{abstract}

\section{Introduction}

White-tailed deer (Odocoileus virginianus Zimm.) are keystone herbivores of eastern deciduous forests of North America (McShea and Rappole, 1992; Waller and Alverson, 1997; Rooney, 2001; Rooney and Waller, 2003). In this region, the historic deer population density has been estimated at 4 deer $/ \mathrm{km}^{2}$ or less (McCabe and McCabe, 1984; Alverson et al., 1988; McCabe and McCabe, 1997). The end of commercial hunting, conversion of forested habitat to agriculture, elimination of predators, and regulation of sport hunting led to an increased deer population density, with recent measurements ranging from $10 / \mathrm{km}^{2}$ to $>60 / \mathrm{km}^{2}$ (e.g. Whitney, 1990; Diefenbach et al., 1997; Russell et al., 2001; Horsley et al., 2003). Extensive research has examined the effects of high deer density. Unsurprisingly, dense deer populations have been shown to influence nearly every aspect of forest understory vegetation and wildlife (see reviews by Alverson et al., 1988; Waller and Alverson, 1997; Russell et al., 2001; Rooney and Waller, 2003; Webster et al., 2018).

One of the most well documented consequences of high deer density is a reduction in tree regeneration due to heavy browse pressure. Studies that have followed the fate of individual marked seedlings (Boerner and
Brinkman, 1996; Stange and Shea, 1998; Rossell et al., 2005; Tremblay et al., 2007; Aronson and Handel, 2011) have shown that seedlings exposed to high deer densities have elevated mortality rates. Other studies have established enclosures stocked with a range of deer densities (Tilghman, 1989; Horsley et al., 2003; Tremblay et al., 2006, 2007; Nuttle et al., 2011, 2014). These have demonstrated that at higher deer densities (> 8-15 deer $/ \mathrm{km}^{2}$ ) regeneration of woody plant species is sharply curtailed, although regeneration of species which are unpalatable to deer is either unaffected or enhanced. Still other studies have compared woody species regeneration between locations with differing deer density (Frelich and Lorimer, 1985; Waller and Alverson, 1997; Rooney et al., 2000, 2002; Rooney and Waller, 2003; Matonis et al., 2011), compared easily accessible vs naturally inaccessible sites (Carson et al., 2005) or revisited locations one or more times (Whitney, 1984; Tremblay et al., 2005). While details differ, all of these studies demonstrate that when deer densities are high, generally $>8.5$ deer $/ \mathrm{km}^{2}$ (Russell et al., 2001), there is a significant reduction in tree regeneration.

Given that deer browse impacts are commonly observed across eastern North America, land managers need to determine how best to respond (McWilliams et al., 2018). Numerous studies have documented

\footnotetext{
* Corresponding author.

E-mail address: john_schmit@nps.gov (J.P. Schmit).
} 
the effects of erecting deer exclosures in forests that are experiencing reduced tree regeneration due to heavy deer browse. In general, excluding deer can increase the density and diversity of tree seedlings and saplings (e.g. Anderson and Loucks, 1979; Marquis, 1974, 1981; Horsley and Marquis, 1983; Long et al., 2007; Rossell et al., 2007; Bourg et al., 2017, and many others, see review by Russell et al., 2001). These studies suggest that reducing deer density may allow tree regeneration to recover.

One means of reducing deer density is to increase mortality through hunting or culling. Royo et al. (2010) studied changes in understory vegetation over seven years in a northern Pennsylvania forest where hunting permits were increased in order to reduce deer densities. Although they did not track tree seedling density, they did show that as deer density declined from $10.4 / \mathrm{km}^{2}$ to $4.9 / \mathrm{km}^{2}$ over 6 years, there was reduced browse on seedlings and increases in populations of palatable understory plants. De la Cretaz and Kelty (2002) studied vegetation in a Massachusetts forest three years after deer density was reduced from 15 to $23 / \mathrm{km}^{2}$ to $1-3 / \mathrm{km}^{2}$. Prior to hunting, tree regeneration was poor, but after deer reduction, seedling densities were markedly higher, except for areas where hay-scented fern (Dennstaedtia punctilobula (Michx.)T. Moore) dominated the understory.

While culling seems like a promising solution, several researchers have noted potential complications that may reduce its effectiveness. Russell et al. (2001) point out that deer exclosure studies inevitably compare ambient deer densities with a complete absence of deer. Deer management, however, will result in an intermediate deer density that may not allow the same vegetation response. Even in exclosures, some studies have shown little vegetation response. Webster et al. (2018) argue that a lack of tree regeneration may not be due to deer alone, but rather the result of multiple interacting stressors. Disturbed forests develop a thick "recalcitrant" understory layer that shades seedlings and impedes forest regeneration (Royo and Carson, 2006). Forests with high deer densities can form recalcitrant understories, such as a thick layer of hay-scented ferns. Exclosure studies have demonstrated that this layer can persist and prevent seedling establishment, even in the absence of deer (Horsley and Marquis, 1983; de la Cretaz and Kelty, 2002; Horsley et al., 2003; Royo and Carson, 2006; Nuttle et al., 2014). These recalcitrant understories with little tree regeneration may form an alternative stable state (Stromayer and Warren, 1997) that will require additional management beyond deer reduction (Horsley et al., 2003; Nuttle et al., 2014). Even if there is not a recalcitrant understory, deer removal may not lead to a complete recovery. As Coomes et al. (2003) point out, reduction in deer density may lead deer to focus on more palatable plants, putting them at a disadvantage compared to less palatable species.

\subsection{Interactions between deer and Microstegium vimineum}

Microstegium vimineum Tin. A. Camus is widespread and aggressive invader of eastern deciduous forests (Huebner, 2010; Brewer, 2011; Flory et al., 2011). There has been considerable concern that interactions between deer and $M$. vimineum can reduce forest tree regeneration more than either can alone and thereby fundamentally change forest ecosystems (Baiser et al., 2008; Johnson et al., 2015). Evidence indicates that high deer densities can facilitate invasion by M. vimineum. A deer exclosure study by Knight et al. (2009) showed that $M$. vimineum was absent in deer exclosure plots but present in control plots accessible to deer. They speculate that its spread is facilitated either due to deer avoiding it but grazing on its competitors, and/or that deer disturb the leaf litter which provides opportunities for $M$. vimineum to become established (Oswalt and Oswalt, 2007). Similarly Bourg et al. (2017) found $M$. vimineum cover was reduced in deer exclosures.

When $M$. vimineum forms dense stands, it has been shown to reduce the density, growth and diversity of native tree seedlings (Oswalt et al., 2007; Aronson and Handel, 2011; Brewer, 2011). The effects of the three way interaction between deer, seedlings, and $M$. vimineum are not entirely clear. Webster et al. (2008) studied tree seedlings in exclosures and controls in Great Smoky Mountains National Park, Tennessee, that had been invaded by $M$. vimineum. They found that exclosures with $M$. vimineum did not initially have a greater woody plant cover or diversity than controls, which indicated that $M$. vimineum could form a recalcitrant understory layer. However, once drought reduced M. vimineum cover, woody species were able to breach the recalcitrant layer and their cover and diversity increased. Aronson and Handel (2011) found that both deer and $M$. vimineum reduced seedling growth and survival, but there was no interaction effect between the two stressors. Johnson et al. (2015) demonstrated that removal of M. vimineum had a positive effect on seedling survival rates and biomass, and that effect on biomass was greater in deer exclosures.

\subsection{Deer management at Catoctin Mountain park}

Catoctin Mountain Park near Thurmont Maryland is a $\sim 2500$ ha unit of the US National Park Service that was first established in 1936. The vegetation in the park is almost entirely second growth eastern deciduous forest (Thomas et al., 2013). It is likely that there were no white-tailed deer living in the park in the 1930s. By the 1980s, however, deer were so numerous that park's staff became concerned about the effect they were having on the native vegetation. After a number of studies were conducted, including estimating the deer population and documenting impacts on tree regeneration using exclosures, the park decided to engage in deer management using annual culling (see National Park Service, 2008 for full details of this decision).

As part of the planning process, National Park Service staff developed a number of objectives for the deer management program. These include: 1) "Reduce adverse effects of deer browsing pressure to ensure tree regeneration sufficient to reach the desired condition of a sustainable eastern hardwood forest with a native and diverse forest structure"; 2) "Maintain, restore and promote a mix of native herbaceous plant species and reduce the competitive advantage of invasive exotic plant species through effective deer management"; and 3) "Maintain a viable white-tailed deer population within the park while protecting other park resources" (National Park Service, 2008).

Deer culling began in February of 2010, and takes place annually in the late fall and winter months. Culling occurs at bait stations placed where there are safe shooting conditions that maximize public safety. These stations include locations both close to and far from roads. Culling is carried out by trained sharpshooters who work during the night to minimize impacts to the public. Based on the work of Horsley et al. (2003), the park adopted 5.9-8 deer $/ \mathrm{km}^{2}$ as a deer density that meets the goal of a viable white-tailed deer population consistent with other park resources, particularly tree regeneration (NPS, 2008). Since 2000, deer densities have been tracked using distance sampling methods on data collected by annual spotlight surveys along park roads (Bates, 2006). These surveys help set targets for the annual cull and take place before culling begins. This method was evaluated at Catoctin to determine if collecting data along the roads was biasing the results (McShea et al., 2011), and no evidence of bias was found. Based on the spotlight survey data, deer populations have declined considerably since deer culling began and currently meet the target density (Bates, 2009, Bates, 2017, Thomas et al., 2013, Fig. 1). Independent of the spotlight sampling, camera trapping was conducted in 2012 and 2013 (Parsons et al., 2017). Based on the camera traps, the density of male deer in the park in each year was 2.49 and 1.65 male deer $/ \mathrm{km}^{2}$ respectively. Using the ratio of adult males to the rest of the population, the authors estimated that total deer density in the park was approximately 12.4 deer $/ \mathrm{km}$ in 2012 and $8.2 \mathrm{deer} / \mathrm{km}$ in 2013 . The 2013 camera trap estimate is slightly lower than the estimate based on distance sampling.

Estimating deer density from roads has been criticized as densities may be different in areas far from roads and distance sampling may not fully account for issues of detectability (e.g. Collier et al., 2013; Beaver et al., 2014; Keever et al., 2017 but see Haus et al., 2019 for an 


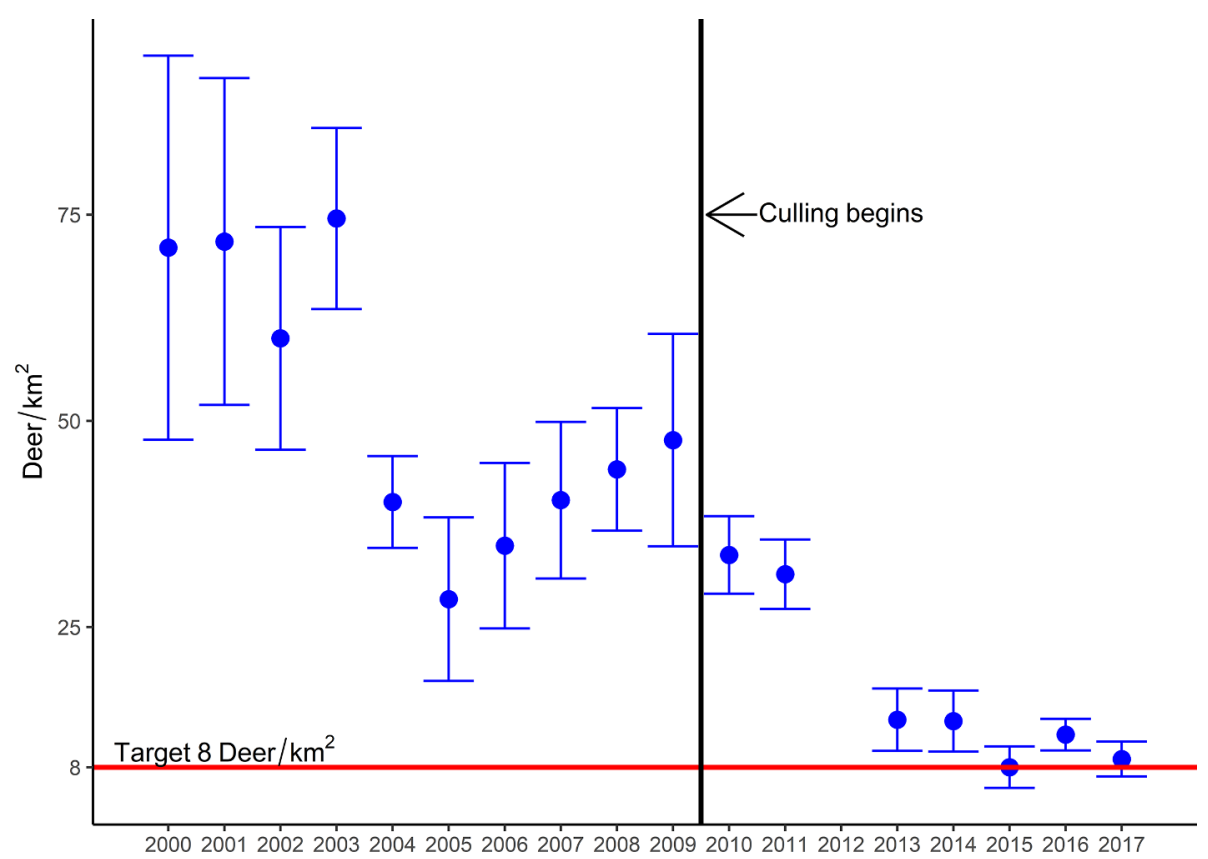

Fig. 1. Estimated white-tailed deer density and 95\% confidence intervals based on spotlight sampling at Catoctin Mountain Park.

empirical comparison of methods). A variety of other density estimation methods have been proposed to address some of these criticisms, including capture-recapture using DNA (Goode et al., 2014, camera trap methods (Keever et al., 2017; Parsons et al., 2017), areal infrared surveys (Beaver et al., 2014), road-based infrared surveys (Haus et al., 2019) and dung transects (Marques et al., 2001), and moving forward, there may be opportunities to refine deer density estimates at Catoctin using one or more of these methods. None-the-less, we are confident that the steep decline in estimated deer density from 2010 onward demonstrates the that culling reduced deer density in the park, even if the spotlight sampling estimates are subject to bias or imprecision.

Given the success in reducing deer density, it is important to determine if the park has been equally successful in increasing tree regeneration, and what impact deer management has had on exotic plants. The most common exotic plant in Catoctin, in the sense of being both widely distributed and having a high percent cover, is Microstegium vimineum (Japanese stiltgrass, Schmit et al., 2012a). This species is found throughout much of the park and often forms dense stands. The spread of this species throughout the park is concerning as it has the potential to curtail the benefits of deer management.

In this paper, we use data from a forest-vegetation monitoring program to track the effects of deer culling on native tree seedlings and on $M$. vimineum. In particular, we ask three questions 1) Has the deer culling led to an increase in native tree seedling density? 2) Does M. vimineum form a recalcitrant understory layer that impedes tree seedlings? 3) Can dense $M$. vimineum cover persist in the absence of high deer densities?

\section{Methods}

\subsection{Field methods}

In 2006, the National Capital Region Inventory and Monitoring Network, a program of the National Park Service, began a forest vegetation-monitoring program at Catoctin Mountain Park. Forty-nine permanent monitoring plots were randomly located in wooded areas of the park using a generalized random tessellation stratified sampling procedure (Stevens and Olsen, 2004).

Each plot consists of a $15 \mathrm{~m}$ radius circle. With the plot, all trees $\geq 10 \mathrm{~cm}$ diameter at breast height (DBH) are tagged and identified. A variety of information is collected about each tree including $\mathrm{DBH}$, presence and identity of climbing vines on the trees, evidence of pests or diseases, and a variety of indicators of tree condition such as the presence of advanced decay, exposed roots, and bark damage. Saplings, defined as woody stems at least 1 and less than $10 \mathrm{~cm} \mathrm{DBH}$, and shrubs are monitored within three $3 \mathrm{~m}$ radius circular microplots located within the main plot. Within each plot, twelve $1 \mathrm{~m}^{2}$ quadrats are sampled for both tree seedlings and $M$. vimineum. Each tree seedling $>15 \mathrm{~cm}$ tall and less than $1 \mathrm{~cm} \mathrm{DBH}$ is monitored and its species identification and height are recorded. $M$. vimineum cover is visually estimated to the nearest percent by field crews. Additional measurements taken from the quadrats include the percent cover of: rocks, coarse woody debris, living tree trunks, and other understory species. For a full description of the monitoring protocol see Schmit et al. (2014).

Plots were randomly assigned to one of four sampling panels, and one panel is monitored every year on a rotating basis. After data has been collected from all four panels, the monitoring cycle repeats, so each plot is monitored once every four years. The first four-year monitoring cycle took place from 2006 to 2009 , entirely before deer management began. Since the start of deer management, two more monitoring cycles (2010-2013 and 2014-2017) have been completed.

The data is available from the National Park Service Data Store at: https://irma.nps.gov/DataStore/Reference/Profile/2267043.

\subsection{Statistical methods}

To determine seedling densities and percent cover of Microstegium within individual sampling cycles, data from all plots was used to calculate the mean. To determine trends over time, we analyzed the data using generalized linear mixed models in a Bayesian framework. Each plot at each monitoring cycle was used as a replicate $(n=147)$. The number of seedlings on each plot was a response variable and was calculated as the total number of seedlings found on the twelve quadrats. $M$. vimineum cover of each plot was either used as a predictor or a response variable, depending on the model (see below). M. vimineum cover of a plot was the mean cover of the 12 quadrats. For statistical modeling, this value was expressed as a proportion (0-1) rather than a percent. As individual plots were sampled only once every four years, we used the monitoring cycle number (1-3) as our measure of time. To account for the repeat sampling of the plots, plot identity was used a random effect in all models. 
To assess the effect of culling and $M$. vimineum on seedling density, we fit a generalized mixed model with a Poisson error structure. Number of seedlings was the response variable and the fixed effects were sampling cycle and $M$. vimineum cover. Sampling cycle was treated as a numeric variable. Some quadrats had living trees, rocky outcrops or coarse woody debris covering part of the forest floor and preventing seedling growth. We were concerned that this effect could mask any effect of $M$. vimineum, as plots with large obstructed areas would be expected to have few seedlings regardless of any other factor. To account for this, the log of the area sampled from each plot, in $\mathrm{m}^{2}$, that was free of such obstructions was included as an offset term. Offset terms are frequently used in generalized linear models to account for differences in area sampled (Kéry, 2010).

The model was analyzed using rjags 4-7 (Plummer, 2018), for $\mathrm{R}$ 3.5.1 (R Core Team, 2018). Uninformative priors for the intercept and two regression coefficients were modeled as normal distributions. For each of these priors the mean was modeled as a normal distribution with mean of 0 and tau ( $=1$ /variance) of 0.001 . For each prior, tau was modeled as a uniform distribution between 0 and 10. The model ran with 3 chains, 1000 iterations for adaption, a 25,000-iteration burn-in period and 800,000 post burn-in iterations. In order to keep chain sizes manageable, chains were thinned to keep only every 50th iteration.

To assess the effect of culling on $M$. vimineum, we fit a zero inflated beta distribution using the zoib 1.5.1 package (Liu and Kong, 2018) for R. $M$. vimineum cover was the response variable and sampling cycle was a fixed effect. $M$. vimineum density appeared to increase and then decrease over time, so cycle was treated as a categorical rather than a numerical variable. As M. vimineum cover can extend over rocks and other obstructions we did not use an offset term with this model. Initial analysis indicated that the shape of the beta distribution and the proportion of plots with no $M$. vimineum did not change over time, so these were modeled using intercepts only. The model was run with 3 chains, a 25,000-iteration burn-in, 150,000 post burn-in iterations, and thinning set to 5 . All other options to the zoib() function were left at the default settings.

For both models, convergence was checked by verifying that the Gelman-Rubin convergence diagnostic was less than 1.05 (Gelman and Rubin, 1992). Chains were plotted to verify adequate mixing. All models were run with sufficient iterations to ensure an effective samples size $>10,000$ (Kruschke, 2015). Statistical significance of terms was assessed using their highest probability density intervals (HPDIs).

\section{Results}

Based on the raw data, seedling density in the park increased approximately 11 fold from the first to the third cycles (Fig. 2).

Prior to culling, there were few seedlings of any height, and all seedlings $>45 \mathrm{~cm}$ tall were exotic (Fig. 3). During the first four years of culling, there was a dramatic increase in native seedlings $<30 \mathrm{~cm}$ tall. In the third cycle, there was a continued increase in small seedlings as well as a modest increase in seedlings $30-60 \mathrm{~cm}$ tall.

Seedlings represented both overstory (Acer, Betula, Carya, Fagus, Quercus, etc.) and understory (Aralia, Asimina, and Sassafras) tree species (Fig. 4). However, after culling began, the majority of seedlings were members of the overstory genus Fraxinus, almost entirely Fraxinus americana L. Exotic species (Ailanthus altissima (Mill.) Swingle, and Prunus avium (L.) L.) made up a small percentage of the seedlings after the first sampling cycle.

The model of seedling density (Table 1 ) indicated that both time and cover of $M$. vimineum had significant effects. As expected, seedling density increased over time. The coefficient on cycle was 0.84 (HPDI: 0.52-1.15) indicating a 2.3 fold increase (HPDI: 1.7-3.2) per four year cycle.

$M$. vimineum cover also had a positive effect on seedling density. The coefficient on $M$. vimineum cover was 0.035 (HPDI: 0.009-0.059) indicating a 1.04 fold increase (HPDI: 1.01-1.06) for every additional percent of cover. The HPDIs for each of these coefficients does not include zero.

Fig. 5 summarizes the joint impact of these two factors. The effect on seedling density of small changes in $M$. vimineum cover is negligible,

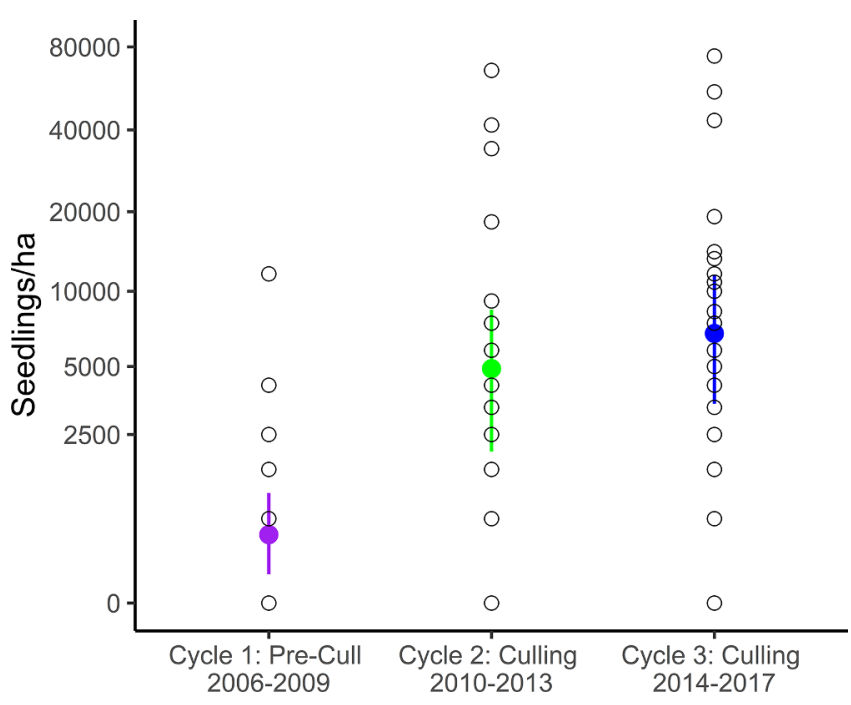

Fig. 2. Number of seedlings/ha at Catoctin by sampling cycle. Filled circles indicate mean values, and lines indicate bootstrap 95\% confidence intervals. Open circles are data from individual plots. Note the logarithmic scale of the $y$ axis. During each cycle, 49 plots were monitored, but many had identical numbers of seedlings, resulting in fewer points on the graph.

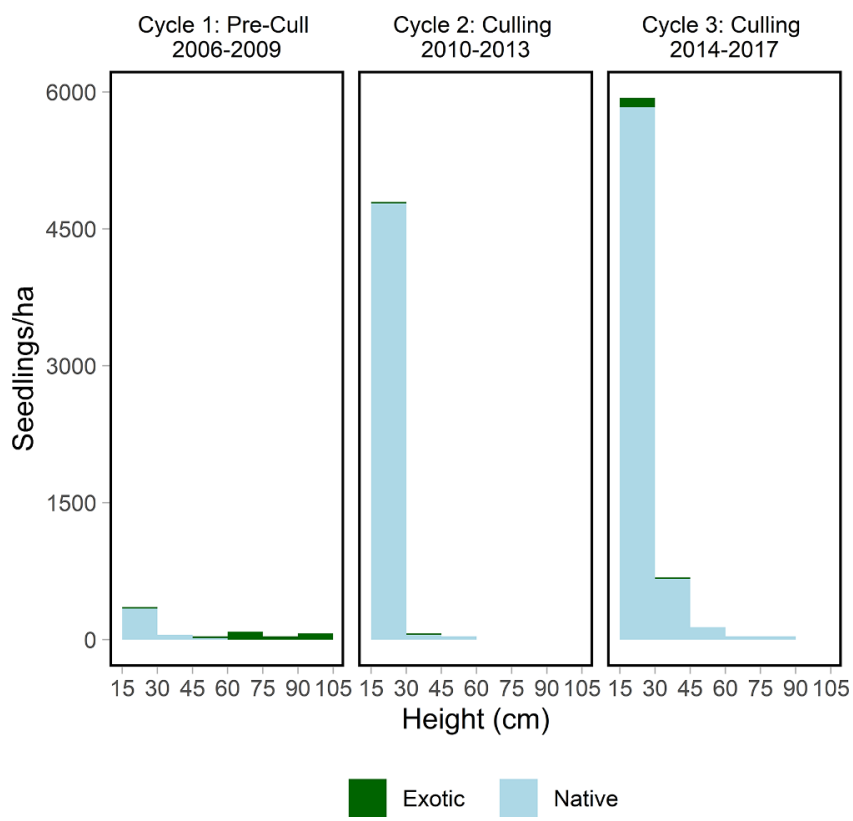

Fig. 3. Histogram of seedling height by nativity and sampling cycle. Data are pooled across all 49 plots.

but the difference between uninvaded and heavily invaded sites is considerable. Plots monitored in Cycle 3 with high $M$. vimineum cover had markedly higher seedling density than plots with low cover in the first cycle. M. vimineum cover was typically less than $50 \%$, but occasionally reached over $75 \%$.

M. vimineum cover showed considerable variation across the park (Fig. 6), ranging from 0 to $80 \%$ cover. During Cycle 1, mean cover was approximately $12 \%$. This increased to $17 \%$ during Cycle 2, before dropping to $11 \%$ during Cycle 3 .

The model indicates that there were significant differences in $M$. vimineum cover between cycles (Table 2). The $\beta$ coefficient for the mean of Cycle 2 was estimated as 0.57 , with HPDI of $0.17-0.96$. As this coefficient was greater than and did not overlap 0 , this indicates an increase of $M$. vimineum cover compared to the pre-cull data. There was no evidence that the $\beta$ coefficient of Cycle 3 (HPDI -0.60 to 0.23 , mean 


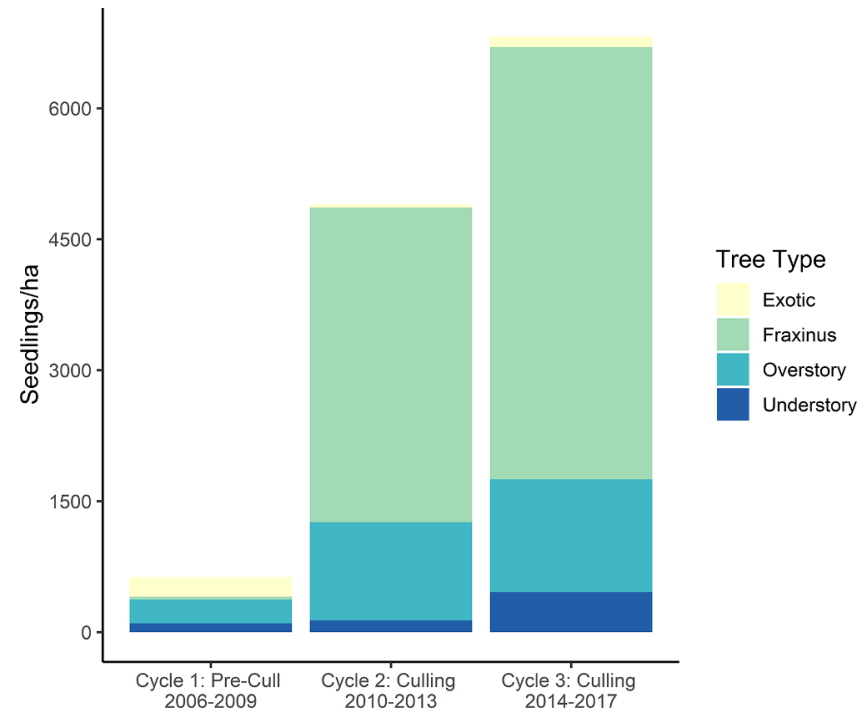

Fig. 4. Seedling type by sampling cycle. Data are pooled across all 49 plots.

Table 1

Seedling count per plot model coefficients ( $\beta$ ). Mean - estimated value, 95\% CI - credible interval defined as the $95 \%$ highest probability density interval.

\begin{tabular}{llll}
\hline Coefficient & Estimate & $95 \%$ CI & Gelman-Rubin diagnostic \\
\hline Intercept & -2.88 & -3.69 to -2.09 & 1.00 \\
$\beta_{\text {Cycle }}$ & 0.84 & $0.52-1.15$ & 1.00 \\
$\beta_{\text {Microstegium }}$ & 0.035 & $0.009-0.59$ & 1.00 \\
\hline
\end{tabular}

- 0.18) differed from zero. However, there was a significant difference between the coefficients of Cycles 2 and 3 (mean 0.76, HPDI $0.37-1.15$ ), indicating that Cycle 2 had higher $M$. vimineum cover than Cycle 3, but that cover in Cycle 3 retuned to the levels seen in Cycle 1 and did not significantly differ from the cover observed pre-cull.

Taken together the results showed that after deer culling began seedling densities increased in the park but the extent of this increase varied from plot to plot, based in part on the percent cover of $M$.

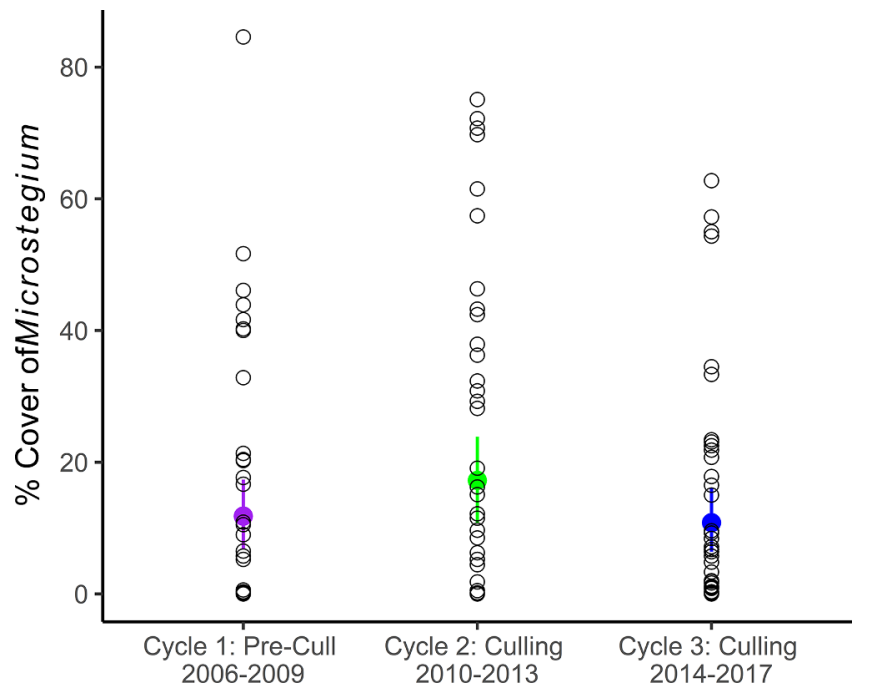

Fig. 6. Percent cover of $M$. vimineum per plot at Catoctin, by sampling cycle. Filled circles indicate mean values and lines indicate bootstrap 95\% confidence intervals. Open circles are data from individual plots. During each cycle, 49 plots were monitored, but some may have had similar cover resulting in fewer points on the graph.

Table 2

Microstegium vimineum cover per plot beta regression model coefficients (Inetercept, $\beta$ ), shape parameter of the beta distribution (Shape), probability that a plot has no M. vimineum $\left(\mathrm{P}_{0}\right)$ and error term $(\sigma)$ Mean - estimated value, $95 \%$ CI - credible interval defined as the $95 \%$ highest probability density interval.

\begin{tabular}{llll}
\hline Coefficient & Mean & $95 \%$ CI & Gelman - Rubin diagnostic \\
\hline Intercept & -2.05 & -2.62 to -1.47 & 1.00 \\
$\beta_{\text {Cycle 2 }}$ & 0.57 & $0.17-0.96$ & 1.00 \\
$\mathrm{~B}_{\text {Cycle } 3}$ & -0.18 & -0.60 to 0.23 & 1.00 \\
Shape & 2.34 & $1.93-2.74$ & 1.00 \\
$\mathrm{P}_{0}$ & -0.55 & -0.88 to -0.21 & 1.00 \\
$\sigma$ & 1.90 & $0.88-3.10$ & 1.00 \\
\hline
\end{tabular}

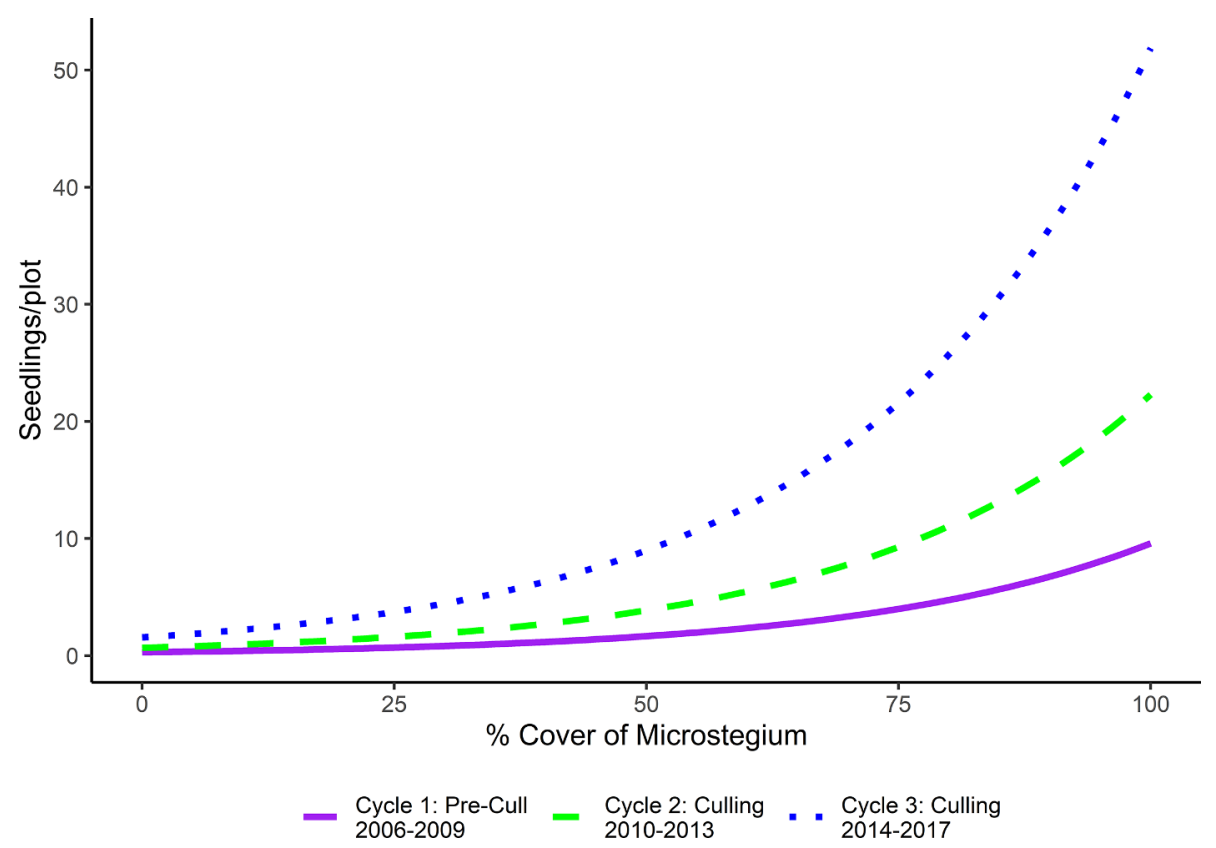

Fig. 5. Predicted number of seedlings per plot vs. M. vimineum cover. Seedlings are monitored on $121 \mathrm{~m}^{2}$ quadrats in each plot. Each line represents a sampling cycle. The model indicates seedling density increased through time and with increasing $M$. vimineum cover. 
vimineum. Plots with a higher cover of $M$. vimineum had larger increases in seedling density. $M$. vimineum initially increased in cover, but by the 2014-2017 monitoring cycle had returned to its pre-culling levels, which coincided with smaller increases in seedling density compared to the gains in the first four years after culling began.

\section{Discussion}

During the first eight years, the deer management program at Catoctin Mountain Park has met with initial success. Deer density was reduced to a level that allows an increase in tree seedling density, an important first step in restoring native tree regeneration. Cover of the exotic invasive $M$. vimineum initially increased during the first four years of culling, but then decreased to the pre-cull level after 8 years of culling, indicating that it may be not be able to dominate the understory without high deer density. Webster et al. (2008) indicated that once a native understory is able to pierce the $M$. vimineum layer, $M$. vimineum may be further suppressed by the increased shading. While it is premature to conclude that $M$. vimineum will continue to decline, it is worth noting that other exotic plant species, such as Alliaria petiolata (garlic mustard), undergo steep declines in deer exclosures and also may be dependent on deer to maintain its population (Kalisz et al., 2014).

Once deer density was reduced, $M$. vimineum did not form a recalcitrant understory. Somewhat surprisingly, seedling density was higher in areas of high $M$. vimineum cover. This is in contrast to studies that found a negative effect of $M$. vimineum in the complete absence of deer (Aronson and Handel, 2011; Johnson et al., 2015), and shows that even at low densities, deer play an important role in structuring forest communities. These low deer density effects are not present in exclosures, which limits their utility in predicting the outcome of management efforts.

Our study does not directly address the drivers of the seedling $-M$. vimineum relationship. It may simply be that microhabitats that are most favorable for $M$. vimineum are also favorable for seedlings, and there is little interaction between species. However, it may be that $M$. vimineum indirectly aids in seedling growth. Stange and Shea (1998) studied a restoration project in which fabric mats were placed around seedlings to prevent competition from other plants. Compared to controls, treated seedlings were more frequently browsed by white-tailed deer and suffered higher mortality, likely because mats made them more conspicuous. Johnson et al. (2015) found that the increase in seedlings biomass when $M$. vimineum is removed is enhanced in exclosures, and concluded that $M$. vimineum provides protection to seedlings from deer outside exclosure. A similar mechanism could be at work at Catoctin, where seedlings growing amongst $M$. vimineum may be effectively camouflaged and avoid deer browse. This phenomenon of deer avoiding palatable species when found in association with unpalatable species has been called associational resistance (Barbosa et al., 2009). Tanentzap et al. (2012) reviewed several studies from across the globe showing associational resistance and concluded that it can lead to non-linear and spatially uneven rates of recovery that depend not just on deer density but also on the composition of the surrounding vegetation community.

Although the results of the deer management program are promising, there has not yet been sufficient tree regeneration to sustain the native forests in the park. Webster et al. (2018), in a discussion of the processes controlling change in forest understories, emphasize that resilience in plant populations depends on individuals successfully transitioning between life history stages. Due to the deer management, once seedlings sprout they are able to reach the $15 \mathrm{~cm}$ height required to be detected by our monitoring. However, few seedlings are making the transition from seedling to sapling stage. Over the course of the study, our monitoring indicates that sapling density dropped from 272 saplings/ha in the 2006-2009 pre-cull cycle to 205 saplings/ha in the 2014-2017 monitoring cycle. Few seedlings have grown over $30 \mathrm{~cm}$ in height (Fig. 3) and none have grown over $1 \mathrm{~m}$. Given the slow recruitment of seedlings into height classes $>90 \mathrm{~cm}$ tall, we expect it will take many years before any reach the sapling stage $(\mathrm{dbh}>1 \mathrm{~cm}$, typically between 1.5 and $2.0 \mathrm{~m}$ tall) and sapling density levels off or increases.

Recovery from overbrowsing can also be delayed by factors unrelated to deer. The seedlings that have established are from a wide variety of species, but the majority are Fraxinus americana. In some studies Fraxinus has been shown to dominate seedling communities, particularly the smaller size classes (Boerner and Brinkman, 1996; de la Cretaz and Kelty, 2002; Aronson and Handel, 2011). Fraxinus trees are experiencing high mortality in the park due to infestation with emerald ash borer (EAB - Agrilus planipennis Fairmaire), an exotic pest. Prior to the outbreak of $\mathrm{EAB}, F$. americana was a common canopy tree in the park (Schmit et al., 2012b), and its regeneration would have been important for a sustainable forest. As seed bearing trees are eliminated from the park, there will be no source of new seedlings. The population of existing $F$. americana seedlings will be reduced by mortality so that few if any of the $F$. americana seedlings will become canopy trees. Long term canopy tree regeneration will be dependent on the minority of seedlings that are from other canopy species.

Although we are unaware of any studies that quantify recovery time in forests similar to that of Catoctin, the rate of recovery from overbrowsing seen in the park is similar to that seen in other forested ecosystems. Long et al. (2007) note that recovery of some species may be delayed for years until they have an abundant seed crop and recruit significant numbers of seedlings. In studies of heavily browsed hemlock forests in Wisconsin, USA (Anderson and Loucks, 1979; Anderson and Katz, 1993), it took twelve years for exclosures to show recovery of seedlings and twenty-seven years for saplings and small trees to recover. Anderson and Katz (1993) speculate that in regions with a long history of over-browsing, tree recovery may take up to seventy years. Tanentzap et al. (2009) found that even after forty years of deer management in a Nothofagus in forest New Zealand, compared to controls, exclosures had more saplings particularly of more palatable trees species. After 12 years of deer management in deciduous forests in Ontario, Canada (Tanentzap et al., 2011), the density of saplings $<2 \mathrm{~cm} \mathrm{dbh}$ had increased, but trees 2-12 cm DBH decreased, due to the legacy of previous browse, and exclosures had significantly more tree regeneration than plots exposed to deer. Tree species sensitive to deer browse only recovered in deer exclosures.

A variety of mechanisms may be responsible for the slow pace of vegetation recovery seen in those studies. The mechanisms can include not just recalcitrant understories, but also slow growth rates, a lack of propagules of affected plant species, unfavorable abiotic conditions for seedling establishment, and deer diet switching to browse-preferred species and consuming their biomass faster than it is produced (Tanentzap et al., 2012). These issues are even more pronounced amongst herbaceous understory species that cannot grow large enough to escape deer predation (Royo et al., 2010; Pendergast et al., 2016).

Continuing deer management will clearly be necessary if Catoctin Mountain Park is to reach the goal of a sustainable, native and diverse eastern hardwood forest. As recovery continues, managers will be able to assess if additional management actions will be necessary in conjunction with on-going deer management. Previous studies suggest that a reduction in browsing pressure alone may not restore all plant species. Additional stressors to the forest, such as altered fire regimes, pests and pathogens, exotic plants and climate change, could also impede recovery of the forest. Responding to multiple stressors will be an ongoing challenge, requiring a broad program of monitoring and management. Our results indicate that deer culling can be an effective tool in restoring tree regeneration, but that success will require a long-term commitment.

\section{CRediT authorship contribution statement}

John Paul Schmit: Investigation, Data curation, Formal analysis, Writing - original draft. Elizabeth R. Matthews: Investigation, Data curation, Project administration, Writing - review \& editing. Andrejs Brolis: Investigation, Data curation, Writing - review \& editing. 


\section{Declaration of Competing Interest}

All authors are employees of the National Park Service.

\section{Acknowledgements}

We would like to thank Scott Bell, Lindsey Donaldson and Becky Loncosky at Catoctin Mountain Park for their help and support. We would also like to thank the many field crew members who assisted with data collection, particularly Allen Dupre and John Parrish. Bonnie Campbell, Mark Lehman and Geoff Sanders provided invaluable support with data management. Two anonymous reviewers provided helpful criticisms and suggestions. This research did not receive any specific grant from funding agencies in the public, commercial, or notfor-profit sectors.

\section{Appendix A. Supplementary material}

Supplementary data to this article can be found online at https:// doi.org/10.1016/j.foreco.2020.118015.

\section{References}

Alverson, W.S., Waller, D.M., Solheim, S.L., 1988. Forests too deer: edge effects in Northern Wisconsin. Conserv. Biol. 2, 348-358. https://doi.org/10.1111/j.15231739.1988.tb00199.x.

Anderson, R.C., Katz, A.J., 1993. Recovery of browse-sensitive tree species following release from white-tailed deer Odocoileus virginianus Zimmerman browsing pressure. Biol. Conserv. 63, 203-208. https://doi.org/10.1016/0006-3207(93)90713-B.

Anderson, R.C., Loucks, O.L., 1979. White-tail deer (Odocoileus virginianus) influence on structure and composition of Tsuga canadensis forests. J. Appl. Ecol. 16, 855-861. https://doi.org/10.2307/2402859.

Aronson, F.M.J., Handel, S.N., 2011. Deer and invasive plant species suppress forest herbaceous communities and canopy tree regeneration. Nat. Areas J. 31, 400-407. https://doi.org/10.3375/043.031.0410.

Baiser, B., Lockwood, J.L., La Pluma, D., Aronson, M.F.J., 2008. A perfect storm: two ecosystem engineers interact to degrade deciduous forests of New Jersey. Biol. Invasions 10, 785-795. https://doi.org/10.1007/s10530-008-9247-9.

Barbosa, P., Hines, J., Kaplan, I., Martinson, H., Szczepaniec, A., Szendrei, Z., 2009. Associational resistance and associational susceptibility: having right or wrong neighbors. Ann. Rev. Ecol. Evolut. Syst. 40, 1-20. https://doi.org/10.1146/annurev. ecolsys.110308.120242.

Bates, S., 2006. White-tailed deer density monitoring protocol version 1.1: Distance and pellet group surveys. National Capital Region Network Inventory and Monitoring Program. Washington DC USA, https://irma.nps.gov/DataStore/Reference/Profile/ 2192470.

Bates, S., 2009. National Capital Region Network 2008 Deer Monitoring Report. Natural Resource Technical Report NPS/NCRN/NRTR 2009/275. National Park Service. Fort Collins, Colorado, https://irma.nps.gov/DataStore/Reference/Profile/663543.

Bates, S., 2017. National Capital Region Deer Report. National Park Service unpublished report.

Beaver, J.T., Harper, C.A., Kissell Jr, R.E., Muller, L.I., Basinger, P.S., Goode, M.J., Van Manen, F.T., Winton, W., Kennedy, M.L., 2014. Aerial vertical-looking infrared imagery to evaluate bias of distance sampling techniques for white-tailed deer. Wildl. Soc. Bull. 38 (2), 419-427. https://doi.org/10.1002/wsb.410.

Boerner, R.E.J., Brinkman, J.A., 1996. Ten years of tree seedling establishment and mortality in an Ohio deciduous forest complex. Bull. Torrey Bot. Club 123, 309-317. https://doi.org/10.2307/2996780.

Bourg, N.A., McShea, W.J., Hermann, V., Stewart, C.M., 2017. Interactive effects of deer exclusion and exotic plant removal on deciduous forest understory communities. AoB PLANTS 9, plx046. https://doi.org/10.1093/aobpla/plx046.

Brewer, J.S., 2011. Per capita community-level effects of an invasive grass, Microstegium vimineum on vegetation in mesic forests in northern Mississippi (USA). Biol. Invasions 13, 701-715. https://doi.org/10.1007/s10530-010-9861-1.

Carson, W.P., Banta, J.A., Royo, A.A., Kirschbaum, C., 2005. Plant communities growing on boulders in the Allegheny National Forest: evidence for boulders as refugia from deer and as a bioassay of overbrowsing. Nat. Areas J. 25, 10-18.

Collier, B.A., Ditchkoff, S.S., Ruth Jr, C.R., Raglin, J.P., 2013. Spotlight surveys for whitetailed deer: monitoring panacea or exercise in futility? J. Wildl. Manag. 77 (1), 165-171. https://doi.org/10.1002/jwmg. 444.

Coomes, D.A., Allen, R.B., Forsyth, D.M., Lee, W.G., 2003. Factors preventing the recovery of New Zealand forests following control of invasive deer. Conserv. Biol. 17, 450-459. https://doi.org/10.1046/j.1523-1739.2003.15099.x.

de la Cretaz, A.L., Kelty, M.J., 2002. Development of tree regeneration in fern-dominated forest understories after reduction of deer browsing. Restor. Ecol. 10, 416-426. https://doi.org/10.1046/j.1526-100X.2002.02037.x.

Diefenbach, D.R., Palmer, W.L., Shope, W.K., 1997. Attitudes of Pennsylvania Sportsmen towards managing white-tailed deer to protect the ecological integrity of forests. Wildl. Soc. Bull. 25, 244-251. https://www.jstor.org/stable/3783438.
Flory, L., Long, F., Clay, K., 2011. Invasive "Microstegium" populations consistently outperform native range populations across diverse environments. Ecology 92, 2248-2257. https://doi.org/10.1890/11-0363.1.

Frelich and Lorimer, 1985. Current and predicted long-term effects of deer browsing in hemlock forests in Michigan USA. Biol. Conserv. 34, 99-120. https://doi.org/10. 1016/0006-3207(85)90103-X.

Gelman, A., Rubin, D.B., 1992. Inference from iterative simulation using multiple sequences. Stat. Sci. 7, 457-511. https://doi.org/10.1214/ss/1177011136.

Goode, M.J., Beaver, J.T., Muller, L.I., Clark, J.D., van Manen, F.T., Harper, C.A. Basinger., P.S., 2014. Capture-recapture of white-tailed deer using DNA from fecal pellet groups. Wildl. Biol. 20, 270-278. https://doi.org/10.2981/wlb.00050.

Haus, J.M., Eyler, T.B., Bowman, J.L., 2019. A spatially and temporally concurrent comparison of popular abundance estimators for white-tailed deer. Northeastern Nat. 26, 305-324. https://doi.org/10.1656/045.026.0207.

Horsley, S.B., Marquis, D.A., 1983. Interference by weeds and deer with Allegheny hardwood reproduction. Can. J. For. Res. 13, 61-69. https://doi.org/10.1139/x83009.

Horsley, S.B., Stout, S.L., deCalesta, D.S., 2003. White-tailed deer impact on the vegetation dynamics of a northern hardwood forest. Ecol. Appl. 13, 98-118. https://doi. org/10.1890/1051-0761(2003) 013[0098:WTDIOT]2.0.CO;2.

Huebner, C.D., 2010. Establishment of an invasive grass in closed-canopy deciduous forests across local and regional environmental gradients. Biol. Invasions 12, 2069-2080. https://doi.org/10.1007/s10530-009-9609-y.

Johnson, D.J., Florey, S.L., Shelton, A., Huebner, C., Clay, K., 2015. Interactive effects of a non-native invasive grass Microstegium vimineum and herbivore exclusion on experimental tree regeneration under differing forest management. J. Appl. Ecol. 52, 210-219. https://doi.org/10.1111/1365-2664.12356.

Kalisz, S., Spigler, R.B., Horvitz, C.C., 2014. In a long-term experimental demography study, excluding ungulates reversed invader's explosive population growth rate and restored natives. In: Proceedings of the National Academy of Sciences, pp. 4501-4506. https://doi.org/10.1073/pnas.1310121111.

Keever, A.C., McGowan, C.P., Ditchkoff, S.S., Acker, P.K., Grand, J.B., Newbolt, C.H., 2017. Efficacy of N-mixture models for surveying and monitoring white-tailed deer populations. Mammal Res. 63, 413-422. https://doi.org/10.1007/s13364-0170319-z.

Kéry, M., 2010. Introduction to WinBugs for Ecologists. Academic Press, Burlington MA, https://doi.org/10.1016/C2009-0-30639-X.

Knight, T.M., Dunn, J.L., Smith, L.A., Davis, J.A., Kalisz, S., 2009. Deer facilitate invasive plant success in a Pennsylvania forest understory. Nat. Areas J. 29, 110-116. https:// doi.org/10.3375/043.029.0202.

Kruschke, J.K., 2015. Doing Bayesian Data Analysis. A tutorial with R, JAGS and Stan. Academic Press, London, UK.

Liu, F., Kong, Y., 2018. zoib: Bayesian inferences for beta regression and zero-or-one inflated beta regression. R package version 1.5.1, 10.1177/0962280216650699, https://CRAN.R-project.org/package = zoib.

Long, Z.T., Prendergast IV, T.H., Carson, W.P., 2007. The impact of deer on relationships between tree growth and mortality in an old-growth beech-maple forest. For. Ecol. Manage. 252, 230-238. https://doi.org/10.1016/j.foreco.2007.06.034.

Marquis, DA. 1974. Deer browsing on Allegheny Hardwood regeneration. US Forest Service Research paper NE-308.

Marquis, DA. 1981. Effects of deer browsing on timber production in Allegheny hardwood forests of northwestern Pennsylvania. United Stated Department of Agriculture. Forest Service Research Paper NE-475.

Marques, F.F.C., Buckland, S.T., Goffin, D., Dixon, C.E., Borchers, D.L., Mayle, B.A., 2001. Estimating deer abundance from line transect surveys of dung: sika deer in southern Scotland. J. Appl. Ecology 38, 349-363. https://doi.org/10.1046/j.1365-2664.2001. 00584.x.

Matonis, M.S., Walters, M.B., Millington, J.D.A., 2011. Gap-, stand- and landscape-scale factors contribute to poor sugar maple regeneration after timber harvest. For. Ecol. Manage. 262, 286-298. https://doi.org/10.1016/j.foreco.2011.03.034.

McCabe, R.E., McCabe, T.R., 1984. Of slings and arrows: An historical retrospection. In: Halls, L.K. (Ed.), White-Tailed Deer: Ecology and Management. Stackpole Books, Harrisburg PA.

McCabe, T.R., McCabe, R.E., 1997. Recounting whitetails past. In: McShea, W.J., Underwood, H.B., Rappole, J.H. (Eds.), The Science of Overabundance: Deer Ecology and Population Management. Smithsonian Institution Press, Washington DC.

McShea, W.J., Rappole, J.H., 1992. White-tailed deer as keystone species within forest habitats of Virginia. Virginia J. Sci. 43, 177-185.

McShea, W.J., Stewart, C.M., Kearns, L., Bates, S., 2011. Road bias for deer density estimates at 2 national parks in Maryland. Wildl. Soc. Bull. 35, 177-184. https://doi. org/10.1002/wsb.53.

National Park Service, 2008. Final white-tailed deer management plan. Environmenta impact statement. National Park Service. U.S. Department of the Interior. Catoctin Mountain Park. Thurmont, Maryland.

Nuttle, T., Ristau, T.E., Royo, A.A., 2014. Long-term biological legacies of herbivore density in a landscape-scale experiment: forest understories reflect past deer density treatments for at least 20 years. J. Ecol. 102, 221-228. https://doi.org/10.1111/ 1365-2745.12175.

Nuttle, T., Yerger, E.H., Stoleson, S.H., Ristau, T.E., 2011. Legacy of top-down herbivore pressure ricochets back up multiple trophic levels in forest canopies over 30 years. Ecosphere 2: Article 4, 10.1890/ES10-00108.1.

Oswalt, C.M., Oswalt, S.N., 2007. Winter litter disturbance facilitates the spread of the nonnative invasive grass Microstegium vimineum (Trin) A. Camus. Forest Ecol. Manage. 249, 199-203. https://doi.org/10.1016/j.foreco.2007.05.007.

Oswalt, C.M., Oswalt, S.N., Clatterbuck, W.K., 2007. Effects of Microstegium vimineum (Trin.) A. Camus on native woody species density and diversity in a productive 
mixed-hardwood forest in Tennessee. For. Ecol. Manage. 242, 727-732. https://doi. org/10.1016/j.foreco.2007.02.008.

Parsons, A.W., Forrester, T., McShea, W.J., Baker-Whatton, M.C., Millspaugh, J.J., Kays, R., 2017. Do occupancy or detection rates from camera traps reflect deer density? J. Mammol. 98, 1547-1557. https://doi.org/10.1093/jmammal/gyx128.

Pendergast IV, T.H., Hanlon, S.M., Long, Z.M., Royo, A.A., Carson, W.P., 2016. The legacy of deer overabundance: long-term delays in herbaceous understory recovery. Can. J. For. Res. 46, 362-369. https://doi.org/10.1139/cjfr-2015-0280.

Plummer, M., 2018. rjags: Bayesian graphical models using MCMC. R package version 4. 7. https://CRAN.R-project.org/package = rjags.

R Core Team, 2018. R: A language and environment for statistical computing. R Foundation for Statistical Computing, Vienna Austria https://www.R-project.org/.

Rooney, T.P., McCormick, R.J., Solheim, S.L., Waller, D.M., 2000. Regional variation in recruitment of hemlock seedlings and saplings in the upper Great Lakes USA. Ecol. Appl. 10, 1119-1132. https://doi.org/10.1890/1051-0761(2000) 010[1119:RVIROH]2.0.CO;2.

Rooney, T.P., 2001. Deer impacts on forest ecosystems: a North American perspective. Forestry 74, 201-208. https://doi.org/10.1093/forestry/74.3.201.

Rooney, T.P., Solheim, S.L., Waller, D.M., 2002. Factors affecting the regeneration of northern white cedar in lowland forests of the Upper Great Lakes region, USA. For Ecol. Manage. 163, 119-130. https://doi.org/10.1016/S0378-1127(01)00532-1.

Rooney, T.P., Waller, D.W., 2003. Direct and indirect effects of white-tailed deer in forest ecosystems. For. Ecol. Manage. 181, 165-176. https://doi.org/10.1016/S03781127(03)00130-0.

Rossell Jr., C.R., Gorsira, B., Patch, S., 2005. Effects of white-tailed deer on vegetation structure and woody seedling composition in three forest types on the Piedmont Plateau. For. Ecol. Manage. 210, 414-424. https://doi.org/10.1016/j.foreco.2005. 02.035 .

Rossell Jr., C.R., Patch, S., Salmons, S., 2007. Effects of deer browsing on native and nonnative vegetation in a mixed oak-beech forest on the Atlantic coastal plain. Northeastern Nat. 14, 61-72. https://doi.org/10.1656/1092-6194(2007) 14[61:EODBON]2.0.CO;2.

Royo, A.A., Carson, W.P., 2006. On the formation of dense understory layers in forests worldwide: consequences and implications for forest dynamics, biodiversity and succession. Can. J. For. Res. 36, 1345-1362. https://doi.org/10.1139/x06-025.

Royo, A.A., Stout, S.L., deCalesta, D.S., Pierson, T.G., 2010. Restoring forest herb communities through landscape-level deer herd reductions: is recovery limited by legacy effects? Biol. Conserv. 143, 2425-2434. https://doi.org/10.1016/j.biocon.2010.05. 020 .

Russell, F.L., Zippin, D.B., Fowler, N.L., 2001. Effects of white-tailed deer (Odocoileus virginianus) on plants, plant populations and communities: a review. Am. Midland Nat. 146, 1-26. https://doi.org/10.1674/0003-0031(2001) 146[0001:EOWTDO]2.0. $\mathrm{CO} ; 2$.

Schmit, J.P., Parrish, J., Campbell, J.P., 2012a. National Capital Region Network: 20062009 forest pest, pathogen and exotic plant status report. Natural Resource Technical Report NPS/NCRN/NRTR-2012/650. National Park Service, Fort Collins, Colorado, https://irma.nps.gov/DataStore/Reference/Profile/2191699.

Schmit, J.P., Parrish, J., Campbell, J.P., 2012b. National Capital Region Network 2006:2009 Forest Vegetation Status Report. Natural Resource Technical Report NPS/ NCRN/NRTR-2012/570. National Park Service, Fort Collins, Colorado, https:// irma.nps.gov/DataStore/Reference/Profile/2184360.

Schmit, J.P., Sanders, G., Lehman, M., Paradis, T., Matthews, E., 2014. National Capital Region Network Long-Term Forest Vegetation Monitoring Protocol: Version 2.1 (March, 2014). Natural Resource Report. NPS/NCRN/NRR-2009/113. National Park Service. Fort Collins, Colorado, https://irma.nps.gov/DataStore/Reference/ Profile/2210263.

Stange, E.E., Shea, K.L., 1998. Effects of deer browsing, fabric mats and tree shelters on Quercus rubra seedlings. Restor. Ecol. 6, 29-34. https://doi.org/10.1046/j.1526- 100x.1998.00614.x.

Stevens, D.L., Olsen, A.N., 2004. Spatially balanced sapling of natural resources. J. Am. Stat. Soc. 99, 262-278. https://doi.org/10.1198/016214504000000250.

Stromayer, K.A.K., Warren, R.J., 1997. Are overabundant deer herds in the eastern United States creating alternate stable states in forest plant communities? Wildl. Soc. Bull. 25, 227-234. https://www.jstor.org/stable/3783436.

Tanentzap, A.J., Bazely, D.R., Koh, S., Timciska, M., Haggith, E.G., Carleton, T.J., Coomes, D.A., 2011. Seeing the forest for the deer: do reductions in deer disturbance lead to forest recovery? Biol. Conserv. 144, 376-382. https://doi.org/10.1016/j. biocon.2010.09.015.

Tanentzap, A.J., Burrows, L.E., Lee, W.G., Nugent, G., Maxwell, J.M., Coomes, D.A., 2009. Landscape-level vegetation recovery from herbivory: progress after four decades of invasive red deer control. J. Appl. Ecol. 45, 1064-1072. https://doi.org/10.1111/j. 1365-2664.2009.01683.x.

Tanentzap, A.J., Kirby, K.J., Goldberg, E., 2012. Slow responses of ecosystems to reductions in deer (Cervidae) populations and strategies for achieving recovery. For. Ecol. Manage. 264, 159-166. https://doi.org/10.1016/j.foreco.2011.10.005.

Thomas, J.E., Bell, P.S., Campbell, J.P., Costanzo, S.D., Dennison, W.C., Dennison, W.C., Donaldson, L., Lehman, M., Loncosky, R., Nortrup, M., 2013. Catoctin Mountain Park, natural resource condition assessment: National Capital Region. Natural Resource Report NPS/CATO/NRR-2013/745. National Park Service, Fort Collings, Colorado, https://irma.nps.gov/DataStore/Reference/Profile/2205987.

Tilghman, N.G., 1989. Impacts of white-tailed deer on forest regeneration in northwestern Pennsylvania. J. Wildl. Manag. 53, 524-532. https://doi.org/10.2307/ 3809172.

Tremblay, J.-P., Thibault, I., Dussault, C., Huot, J., Côté, S.D., 2005. Long-term decline in white-tailed deer browse supply: can lichens and litterfall act as alternative food sources that preclude density-dependent feedbacks. Can. J. Zool. 83, 1087-1096. https://doi.org/10.1139/z05-090.

Tremblay, J.-P., Huot, J., Potvin, F., 2006. Divergent nonlinear responses of the boreal forest field layer along an experimental gradient of deer densities. Oecologia 150 78-88. https://doi.org/10.1007/s00442-006-0504-2.

Tremblay, J.-P., Huot, J., Potvin, F., 2007. Density-related effects of deer browsing on the regeneration dynamics of boreal forests. J. Appl. Ecol. 44, 552-562. https://doi.org/ 10.1111/j.1365-2664.2007.01290.x.

Waller and Alverson, 1997. The white-tailed deer: a keystone herbivore. Wildlife Soc. Bull. 25, 217-226. https://www.jstor.org/stable/3783435.

Webster, C.R., Dickinson, Y.L., Burton, J.I., Frelich, L.E., Jenkins, M.A., Kern, C.C., Raymond, P., Saunders, M.R., Walters, M.B., Willis, J.L., 2018. Promoting and maintaining diversity in contemporary hardwood forests: confronting contemporary drivers of change and the loss of ecological memory. For. Ecol. Manage. 421, 98-108. https://doi.org/10.1016/j.foreco.2018.01.010.

Webster, C.R., Rock, J.H., Froese, R.E., Jenkins, M.A., 2008. Drought-herbivory interaction disrupts competitive displacement of native plants by Microstegium vimineum, 10 year results. Oecologia 157, 497-508. https://doi.org/10.1007/s00442-008-1085-z.

Whitney, G.G., 1984. Fifty years of change in the arboreal vegetation of Heart's Content, an old-growth hemlock - white pine - northern hardwood stand. Ecology 65, 403-408. https://doi.org/10.2307/1941403.

Whitney, G.G., 1990. The history and status of the hemlock-hardwood forests of the Allegheny plateau. J. Ecol. 78, 443-458. https://doi.org/10.2307/2261123.

McWilliams, W.H., J.A. Westfall, P.H. Brose, D.C. Dey, A. W. D'Amato, Y.L. Dickinson, M. A. Fajvan, L.S. Kenefic, C.C. Kern, K.M. Laustsen, S.L. Lehman, R.S. Morin, T.E. Ristau, A.A. Royo, A.M. Stoltman, S.L. Stout. 2018. Subcontinental-scale patterns of large-ungulate herbivory and synoptic review of restoration management implications for midwestern and northeastern forests. Gen. Tech. Rep. NRS-182. Newtown Square, PA: U.S. Department of Agriculture, Forest Service, Northern Research Station. 24 p. https://doi.org/10.2737/NRS-GTR-182. 